\title{
Pengembangan Metode B3 (Bernyanyi, Bercerita, \& Bermain) dalam Meningkatkan Kemampuan Membaca Permulaan pada Anak Usia 5-6 Tahun Di TKQ X
}

\author{
Dewi Yulia*, Asep Dudi Suhardini
}

Prodi Pendidikan Guru PAUD, Fakultas Tarbiyah dan Keguruan, Universitas Islam Bandung, Indonesia.

*dewi04yulia@gmail.com, asepdudiftk.unisba@gmail.com

\begin{abstract}
Development of B3 Methods (Singing, Storytelling \& Playing) in Improving Beginning Reading Skills in Children aged 5-6 Years in Az-Zahra Kindergarten. The method used in this study uses a qualitative research approach which was designed with a DBR (Design Based Research) approach to examine the B3 method development program (Singing, Storytelling \& Playing) in the process of learning to read beginning for children aged 5-6 years. Data collection techniques were carried out by interview, observation, and documentation study. The results of the study illustrate that: 1) The initial reading learning program for children aged 5-6 years is a prioritized program at the school 2) The reading process using the singing method gets a percentage score of $64.25 \%$, while the reading process using the storytelling method gets a percentage score of $56,68 \%$ and the reading process using the play method obtained a percentage score of $77.65 \% .3$ ) The role of learning tools and media is to present learning that is interesting, fun and attracts students' attention to learn.4) The teacher's role in the learning process for early reading is to introduce letters in a good, effective way and be able to create a comfortable classroom atmosphere for students. 5) The indicator of the success of using the B3 method is that students can recognize letters quickly and without coercion, the teacher's way of teaching reading is better and more effective than before.
\end{abstract}

Keywords: Development, B3 Method (Singing, Storytelling \& Playing), Beginning Reading

\begin{abstract}
Abstrak. Pengembangan Metode B3 (Bernyanyi, Bercerita \& Bermain) Dalam Meningkatkan Kemampuan Membaca Permulaan Pada Anak Usia 5-6 Tahun Di Taman Kanak-Kanak Qur'an Az-Zahra Metode yang digunakan dalam penelitian ini menggunakan pendekatan penelitian kualitatif yang di desain dengan pendekatan DBR (Design Based Research) untuk meneliti program pengembangan metode B3 (Bernyanyi, Bercerita \& Bermain) dalam proses pembelajaran membaca permulaan untuk anak usia 5-6 tahun. teknik pengumpulan data dilakukan dengan wawancara, observasi, dan studi dokumentasi. Hasil penelitian menggambarkan bahwa: 1) Program pembelajaran membaca permulaan untuk anak usia 5-6 tahun merupakan program yang diprioritaskan disekolah tersebut 2) Proses membaca menggunakan metode bernyanyi memperoleh skor presentase $64,25 \%$, sedangkan proses membaca menggunakan metode bercerita memperoleh skor presentase $56,68 \%$ dan proses membaca menggunakan metode bermain memperoleh skor presentase $77,65 \%$. 3) Peran alat dan media pembelajaran yaitu untuk menyajikan pembelajaran yang menarik, menyenangkan dan menarik perhatian siswa untuk belajar. 4) Peran guru dalam proses pembelajaran membaca permulaan yaitu mengenalkan huruf dengan cara yang baik, efektif dan mampu menciptakan suasana kelas yang nyaman untuk siswa. 5) Indikator keberhasilan penggunaan metode B3 adalah siswa dapat mengenal huruf dengan cepat dan tanpa adanya pemaksaan, cara guru dalam mengajarkan membaca permulaan lebih baik dan lebih efektif dari sebelumnya
\end{abstract}

Kata Kunci: Pengembangan, Metode B3 (Bernyanyi, Bercerita \& Bermain), Membaca Permulaan. 


\section{A. Pendahuluan}

Pengenalan membaca permulaan kepada anak dapat dikenalkan melaui kegiatan yang menyenangkan dan disesuaikan dengan perkembangan anak sehingga dapat menumbuhkan minat dan keinginan anak untuk membaca. Metode pembelajaran untuk mengenalkan membaca permulaan dapat melalui metode bernyanyi, bercerita dan bermain. Metode bernyanyi, bercerita dan bermain merupakan tiga teknik yang memegang peran penting dalam setiap pembelajaran pada anak usia dini. Kegiatan pengenalan membaca permulaan dapat disampaikan dengan menyenangkan dan menarik bagi anak apabila kegiatan tersebut dikemas melalui bernyanyi, bercerita dan bermain. Inten, D N. dkk (2016)

kegiatan membaca merupakan kemampuan dasar yang harus dimiliki seorang anak untuk mengembangkan keterampilan berbicara serta menumbuhkan minat anak untuk membaca buku. Pengajaran membaca permulaan dapat dilakukan oleh guru melalui kegiatan melihat gambar, bercerita menggunakan buku cerita, menyediakan alat untuk melatih kemampuan membacanya.

Kondisi yang ditemukan pada saat observasi di TKQ Xpada anak usia 5-6 tahun khususnya di TK B yaitu, rendahnya kemampuan anak dalam mengenal huruf dengan tepat. Sebagian anak kebingungan dalam membedakan huruf dan ragu saat mengucapkan huruf. Rendahnya kemampuan mengenal keaksaraan awal pada anak kelompok B di TKQ Az-Zahra, pengenalan pembelajaran membaca permulaan hanya memfokuskan dengan kegiatan menebalkan huruf dan menulis huruf kembali yang diberikan oleh guru. Guru menulis huruf di papan tulis dengan menggunakan spidol tanpa adanya media pembelajaran yang menarik, siswa duduk diam di bangku masing-masing dan mengucapkan kembali apa yang di ucapkan oleh gurunya. Sehingga anak merasa terbebani, dan cepat bosan.

Permasalahan lain yaitu orang tua murid menuntut para guru untuk memberikan pembelajaran membaca, karena sebagian orang tua murid beralasan menyekolahkan anaknya hanya untuk membaca dan menulis saja. Orang tua merasa takut jika anaknya tidak bisa membaca saat masuk sekolah dasar, sebagian sekolah dasar membuat persyaratan baru yaitu anak-anak diwajibkan bisa membaca dan menulis. Dengan adanya persyaratan tersebut para guru anak usia dini sangat bingung, jika para guru anak usia dini memberikan pembelajaran membaca maka dianggap melanggar aturan. Tetapi jika tidak diberikan, orang tua murid memindahkan anaknya ke sekolah lain.

Berdasarkan uraian permasalahan tersebut Peneliti ingin melakukan penelitian dan pengembangan sebuah metode pembelajaran yaitu metode B3 (bernyanyi, bercerita \& bermain) untuk pengembangan aspek perkembangan bahasa anak. Sehubungan dengan hal tersebut maka Peneliti memfokuskan meneliti kemampuan membaca permulaan pada anak usia 5-6 tahun.

Berdasarkan latar belakang yang telah dibuat, maka rumusan masalah di jabarkan didalam pertanyaan penelitian, yaitu sebagai berikut:

1. Apa program pembelajaran membaca permulaan di Taman Kanak-Kanak Qur'an AzZahra?

2. Bagaimana proses pembelajaran membaca permulaan menggunakan metode B3 (Bernyanyi, Bercerita \& Bermain) terhadap siswa?

3. Bagaimana peran alat peraga dan media dalam pembelajaran membaca permulaan ?

4. Bagaimana kemampuan peran guru dalam proses pembelajaran membaca permulaan dengan menggunakan metode B3 (Bernyanyi, Bercerita \& Bermain)?

Berdasarkan latar belakang diatas, maka rumusan masalah dalam penelitian ini yaitu sebagai berikut: “"'Bagaimanakah Mengembangkan Metode B3 (Bernyanyi, Bercerita \& Bermain) Dalam Meningkatkan Kemampuan Membaca Permulaan Pada Anak Usia 5-6 Tahun Di TKQ X?'.Selanjutnya, tujuan dalam penelitian ini diuraikan dalam pokok-pokok sbb.

1. Untuk mengetahui program pembelajaran membaca permulaan di Taman Kanak-Kanak Qur'an Az-Zahra

2. Untuk mengetahui proses pembelajaran membaca permulaan menggunakan metode B3 (Bernyanyi, Bercerita \& Bermain).

3. Untuk mengetahui peran alat peraga dan media dalam pembelajaran membaca permulaan. 
4. Untuk mengetahui kemampuan peran guru dalam proses pembelajaran membaca permulaan dengan menggunakan metode B3 (Bernyanyi, Bercerita \& Bermain).

5. Untuk mengetahui indikator keberhasilan pembelajaran membaca permulaan pada anak usia 5-6 tahun dengan menggunakan metode B3 (Bernyanyi, Bercerita \& Bermain).

\section{B. Metodologi}

Penelitian Pengembangan Metode B3 (bernyanyi, bercerita \& bermain) Dalam Meningkatkan Kemampuan Membaca Permulaan Pada Anak Usia 5-6 Tahun Di Taman Kanak-Kanak AzZahra, menggunakan pendekatan penelitian kualitatif yang di desain dengan pendekatan DBR (Design Based Research). Design Based Research digunakan untuk mengembangkan teori-teori pembelajaran di bidang studi tertentu. Penelitian ini akan difokuskan kepada pengembangan metode pembelajaran sehingga dapat diaplikasikan dalam penelitian berbasis pembelajaran disekolah.

Plomp (2007 : 13), Clark (2013 : 27) dalam Intendia (2016 : 77) menjelaskan bahwa Design Based Research adalah suatu kajian sistematis tentang merancang, mengembangkan dan mengevaluasi intervensi pendidikan seperti program, strategi, dan bahan pembelajaran, produk dan sistem sebagai solusi untuk memecahkan masalah yang kompleks dalam praktik pendidikan, yang bertujuan untuk memajukan pengetahuan tentang karakteristik dan intervensi serta proses perancangan, dan pengembangannya.

Dari tahapan diatas terdapat empat tahapan umum pada metode Design Based Research (DBR), adapun desain dan tahapan dalam penelitian ini yaitu sebagai berikut:

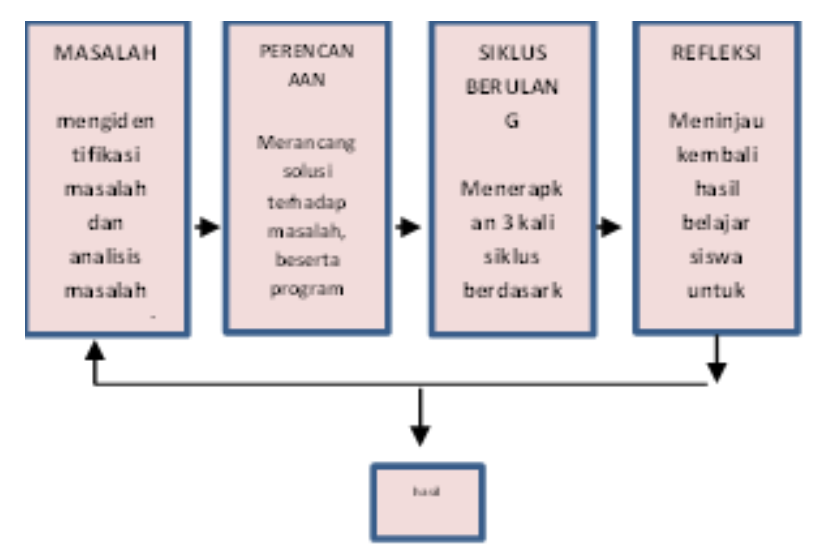

Gambar 1. Desain Penelitian DBR

\section{Hasil dan Pembahasan}

\section{Program Pembelajaran Membaca Permulaan Di Taman Kanak-Kanak Qur'an Az-Zahra}

Program pembelajaran membaca permulaan yang ada di TKQ Xdisesuaikan dengan misi TKQ Xpoint ke empat yaitu kegiatan membaca merupakan hal yang sangat penting untuk mempersiapkan siswa memasuki sekolah dasar. Maka dari itu kegiatan membaca merupakan salah satu prioritas utama yang ada dilembaganya. Program pembelajaran membaca permulaan yang ada di TKQ Xyaitu dilakukan setiap kegiatan awal pembelajaran dan les privat yang dilakukan setelah jam sekolah dengan kurun waktu 1 jam.

Sesuai dengan teori Pertiwi mengungkapkan bahwa membaca permulaan adalah suatu keterampilan dasar pada aspek bahasa anak, yang merupakan bekal utama untuk memasuki jenjang berikutnya. Maka dari itu pembelajaran membaca permulaan merupakan kemampuan utama yang harus dikembangkan, sehingga kemampuan lainnya mengikuti.

Pengertian kemampuan membaca permulaan adalah "kemampuan" merupakan suatu kesanggupan yang dimiliki oleh seseorang untuk melakukan tindakan yang dihasilkan dari pembawaan sejak lahir. Kemampuan akan berkembang jika diberikan latihan-latihan sehingga kemampuan tersebut dapat berkembang dengan baik. Sedangkan "membaca" merupakan salah 
satu penggunaan bahasa untuk menguraikan tulisan atau simbol dan untuk memahaminya. Maka dari itu kemampuan membaca permulaan adalah kemampuan seseorang dalam membaca pada tahap awal yaitu pengenalan huruf, suku kata hingga kalimat sederhana dan unsur-unsur linguistik yang diterima oleh indera penglihatan kemudian dilanjutkan ke otak dan selanjutnya diberikan tafsir atau makna.

Program membaca permulaan yang ada di TKQ Xyaitu pengenalan huruf dari mulai huruf dasar, huruf vokal, suku kata, kata hingga kalimat dengan menggunakan buku atau modul pembelajaran membaca untuk siswa yang telah dibuat oleh Ibu Lien Herlina selaku kepala sekolah dan guru-guru terdahulu pada tahun 2007. Modul sudah jarang digunakan, guru lebih menggunakan buku pegangan sendiri. Buku yang digunakan berupa buku pengenalan huruf yang dibeli di toko online. Adapun metode yang digunakan dalam pengenalan huruf yaitu melalui metode bermain, sedangkan metode yang digunakan setiap hari yaitu siswa maju satu persatu ke meja guru, seteah itu siswa mengucapkan kembali apa yang di ucapkan oleh guru kegiatan tersebut dilakukan 5 sampai 10 menit per siswa. Sedangkan metode pada saat kegiatan les privat yaitu hampir sama dengan metode sebelumnya, hanya saja durasi waktu yang diberikan lebih lama.

\section{Proses Pembelajaran Membaca Permulaan Menggunakan Metode B3 (Bernyanyi, Bercerita \& Bermain)}

Setelah mengetahui program pembelajaran membaca permulaan di TKQ Xlangkah selanjutnya yaitu mengenai proses pembelajaran membaca permulaan dengan menggunakan metode B3 (Bernyanyi, Bercerita \& Bermain). Metode B3 ini diterapkan di kelompok B1, siswa yang akan dipersiapkan membaca untuk masuk sekolah dasar.

Program metode B3 ini di kemas dengan menarik, asyik dan menyenangkan sehingga tidak membebani anak pada saat proses belajar membaca. Sesuai dengan syarat pembelajaran membaca oleh Thomson yaitu pembelajaran harus dikemas dengan menarik, asyik, dan menyenangkan. Pembelajaran membaca permulaan dilakukan dengan permainan-permainan yang menarik sehingga anak merasa senang, dan tanpa disadari anak lebih cepat mengingat huruf yang sedang dipelajari.

Sesuai dengan teori Enny Zubaidah bahwa membaca permulaan ditekankan pada pengenalan dan pengucapan lambang-lambang bunyi yang berupa huruf, kata dan kalimat dalam bentuk sederhana. Huruf didalam bahasa Indonesia terbagi menjadi dua, yakni huruf vokal dan huruf konsonan. Peneliti mengenalkan huruf dasar kepada siswa kelompok B usia 5-6 tahun. Pengenalan huruf diberikan secara bertahap, tahap 1 pengenalan huruf vokal, tahap ke 2 pengenalan suku kata ba,bi,bu,be,be, tahap 3 pengenalan suku kata ca,ci,cu,ce,co dan tahap ke 4 pengenalan suku kata gabungan tahap 2 dan 3 yaitu baca, cabe, boci, buci, dan beca.

Sedangkan teori menurut Piaget bahwa anak usia 5-6 tahun pada aspek perkembangan kognitif anak telah memasuki tahap pra-operasional, yaitu dimana anak sudah dapat belajar menggunakan simbol-simbol. Dari simbol tersebut merupakan tahapan awal anak belajar dalam membaca. Teori ini diaplikasikan melalui kegiatan metode bermain, anak menebak gambar lalu di cocokkan dengan hurufnya. Sesuai dengan hasil penelitian bahwa metode bermain lebih banyak disenangi oleh anak, dan hasil dari penelitian anak lebih cepat mengenal huruf. Selain itu anak cepat mengenal huruf pada saat kegiatan bernyanyi, kegiatan bernyanyi menggunakan media kartu cantol yang dibentuk dan digambar sesuai dengan awalan suku kata, sehingga anak mudah membaca dan memahaminya.

\section{Tahap I}

Hasil kemampuan membaca suku kata dengan nyaring dan lafal yang tepat pada saat kegiatan bernyanyi tahap I di TKQ Xsebagian siswa dengan persentase $50 \%$ sudah berkembang sesuai harapan. Sebagian siswa ada yang sudah berkembang sesuai harapan, dan mulai berkembang. Hasil analisis selanjutnya yaitu analisis kemampuan dalam menyimak dan mengamati huruf pada saat kegiatan bercerita tahap I di TKQ Xmenunjukkan bahwa sebagian besar siswa $50 \%$ berkembang sesuai harapan. Sebagian siswa berada diposisi mulai berkembang dan berkembang sangat baik. Analasis ketiga mengenai kemampuan mengidentifikasi huruf vokal dan konsonan pada saat kegiatan 
bermain tahap I di TKQ Xsebagian besar siswa $60 \%$ berkembang sesuai harapan.

\section{Tahap II}

Hasil analisis kemampuan membaca suku kata dengan nyaring dan lafal yang tepat pada saat kegiatan bernyanyi tahap II di TKQ Xsebagian siswa dengan persentase $67 \%$ sudah berkembang sesuai harapan. Sebagian siswa ada yang sudah berkembang sesuai harapan, dan mulai berkembang. Hasil analisis selanjutnya yaitu analisis kemampuan dalam menyimak dan mengamati huruf pada saat kegiatan bercerita tahap II di TKQ Xmenunjukkan bahwa sebagian besar siswa 66,7 \% berkembang sesuai harapan. Sebagian siswa berada diposisi mulai berkembang dan berkembang sangat baik. Analasis ketiga mengenai kemampuan mengidentifikasi huruf vokal dan konsonan pada saat kegiatan bermain tahap II di TKQ Xsebagian besar siswa 55,6\% berkembang sesuai harapan.

3. Tahap III

Hasil analisis kemampuan membaca suku kata dengan nyaring dan lafal yang tepat pada saat kegiatan bernyanyi tahap III di TKQ Xsebagian siswa dengan persentase $60 \%$ sudah berkembang sesuai harapan. Sebagian siswa ada yang sudah berkembang sesuai harapan, dan mulai berkembang. Hasil analisis selanjutnya yaitu analisis kemampuan dalam menyimak dan mengamati huruf pada saat kegiatan bercerita tahap III di TKQ Xmenunjukkan bahwa sebagian besar siswa 50\% berkembang sesuai harapan. Sebagian siswa berada diposisi mulai berkembang dan berkembang sangat baik. Analasis ketiga mengenai kemampuan mengidentifikasi huruf vokal dan konsonan pada saat kegiatan bermain tahap I di TKQ Xsebagian besar siswa 95\% berkembang sangat baik.

\section{Tahap IV}

Hasil analisis kemampuan membaca suku kata dengan nyaring dan lafal yang tepat pada saat kegiatan bernyanyi tahap IV di TKQ Xsebagian siswa dengan persentase $80 \%$ sudah berkembang sangat baik. Sebagian siswa ada yang sudah berkembang sesuai harapan, dan mulai berkembang. Hasil analisis selanjutnya yaitu analisis kemampuan dalam menyimak dan mengamati huruf pada saat kegiatan bercerita tahap IV di TKQ Xmenunjukkan bahwa sebagian besar siswa $60 \%$ berkembang sesuai harapan. Sebagian siswa berada diposisi mulai berkembang dan berkembang sangat baik. Analasis ketiga mengenai kemampuan mengidentifikasi huruf vokal dan konsonan pada saat kegiatan bermain tahap IV di TKQ Xsebagian besar siswa 100\% berkembang sangat baik.

hasil rekapitulasi tentang metode disetiap tahap dalam proses pembelajaran membaca permulaan untuk anak usia 5-6 tahun di TKQ Xyaitu, Metode bernyanyi memperoleh skor presentase $64,25 \%$, sedangkan metode bercerita memperoleh skor presentase $56,68 \%$ dan metode bermain memperoleh skor presentase $77,65 \%$. Dapat dilihat bahwa renspon siswa terbanyak terhadap metode yang disenangi oleh anak yaitu metode bermain. Metode kedua yang disenangi oleh anak yaitu metode bernyanyi. Metode bercerita kurang diminati siswa kelompok B1 di TKQ Az-Zahra.

Dapat disimpulkan bahwa dari ke 3 point penilaian dari tahap 1 hingga tahap 4, penerapan metode B3 kepada anak dapat berkembang sesuai harapan. Sesuai dengan pendapat Inten, D N. dkk (2016) bahwa pengenalan membaca permulaan kepada anak dapat dikenalkan melaui kegiatan yang menyenangkan dan disesuaikan dengan perkembangan anak sehingga dapat menumbuhkan minat dan keinginan anak untuk membaca. Metode pembelajaran untuk mengenalkan membaca permulaan dapat melalui metode bernyanyi, bercerita dan bermain.

\section{Peran Alat Peraga Dan Media Dalam Pembelajaran Membaca Permulaan}

Analisis peran alat peraga dan media pembelajaran membaca permulaan memiliki peran penting untuk membantu kelancaran, dan pendukung proses pembelajaran membaca permulaan untuk anak usia 5-6 tahun khususnya di kelompok B1. Dengan adanya media kartu cantol, media panggung sandiwara, boneka wayang, dan alat permainan monoca membantu guru dalam menyajikan pembelajaran yang efektif dan membatu guru mengenalkan huruf kepada anak dengan cara yang menyenangkan. Melalui media dan alat pembelajaran siswa antusias dalam 
belajar membaca, respon siswa terhadap alat dan media pembelajaran kartu cantol yaitu sangat bagus, respon media bercerita yaitu biasa saja, dan respon siswa terhadap alat permainan sangat bagus.

Analisis teori Montessori dalam buku (Masnipal, 2017: 33) aktivitas belajar dikelompokkan menjadi tiga area yaitu, practice life atau pendidikan gerak, sensory materials untuk melatih indera, dan academic materials untuk pengajaran membaca dan menulis. Kelompok academic materials yaitu bahan-bahan yang diperlukan untuk mengajarkan anak menulis, membaca dan matematika. Contoh bahan yang digunakan dalam kegiatan membaca yaitu kartu huruf, kartu angka, dan media pembelajaran yang dikhususkan untuk pembelajaran membaca permulaan. Dengan adanya teori tersebut, metode B3 ini dilengkapi dengan media kartu huruf berukuran besar dan dapat dicantolkan, media khusus seperti monoca, menara huruf, kotak hartakarun menyusun suku kata dan doorprize kata.

Alat dan media pembelajaran harus dibuat semenarik mungkin sehingga anak tertarik dan senang saat memainkannya. Sesuai dengan prinsip-prinsip permainan menurut Fadlillah yaitu Menyenangkan dan dapat dinikmati. Sebagaimana telah dijelaskan sebelumnya bahwa dasar dalam kegiatan bermain yaitu memperoleh kesenangan dan kepuasan. Maka dari itu, kegiatan bermain harus memberikan rasa senang, gembira, dan membangkitkan semangat anakanak. Maka dari itu prinsip bermain harus dapat dinikmati dan memunculkan rasa gembira bagi pemainnya.

Respon guru terhadap alat dan media pembelajaran yaitu sangat memuaskan, ungkapan guru terhadap alat dan media pembelajaran yaitu sangat bagus, mulai dari tahap 1 hingga tahap 4. Media dibuat semenarik mungkin, pemilihan warna yang sesuai untuk anak, bentuk dan ukuran sudah sesuai dengan anak sehingga seluruh anak melihat dengan jelas.

\section{Peran Guru Dalam Proses Pembelajaran Membaca Permulaan Dengan Menggunakan Metode B3 (Bernyanyi, Bercerita \& Bermain)}

Analisis tentang peran guru dalam proses pembelajaran membaca permulaan dengan menggunakan metode B3 (Bernyanyi, Bercerita \& Bermain). Kemampuan guru dalam memahami skenario pembelajaran membaca permulaan dengan menggunakan metode sudah cukup baik. Kemampuan ini perlu dikuasai oleh para guru, sehingga mampu memahami konsep pembelajaran yang akan di terapkan dari mulai kegiatan pembuka hingga kegiatan penutup. Dengan adanya skenario atau panduan yang sudah dibuat sebelumnya berfungsi untuk memudahkan para guru dalam proses mengajar.

Peran guru dalam memanfaatkan alat dan media pembelajaran metode B3 sudah sangat baik. Kemampuan dalam menggunakan alat peraga dan media pembelajaran sudah efektif, dilakukan secara berurutan dan guru sudah mampu menciptakan suasana yang menyenangkan. Peran guru dalam proses penggunaan metode B3, kemampuan guru dalam membuka pembelajaran sudah sangat baik. Guru mampu membuka pembelajaran dengan mengenalkan pembelajaran pada hari ini, sehingga pada saat kegiatan inti anak langsung memahaminya. Guru dapat menciptakan suasana hangat dan antusiasme dalam proses belajar dengan baik, sehingga siswa memiliki minat dalam belajar membaca. Kemampuan guru dalam memberikan penguatan sudah sangat bagus, pada tahap ke 4 anak-anak hafal dengan lagu yang sudah dipelajari dari mulai tahap 1 hingga tahap 4.

Sesuai dengan manfaat metode B3 bahwa melalui metode B3 memperbaiki cara guru dalam mengajarkan membaca permulaan untuk anak usia dini yang biasanya dilakukan dengan cara menjejal dan kegiatan yang monoton. Metode B3 membantu para guru untuk mengajarkan membaca permulaan anak usia yang lebih tepat dan efektif, sehingga dapat menarik perhatian anak untuk mengikuti proses pembelaharan membaca permulaan. Sesuai dengan data observasi penelitian bahwa metode B3 membantu guru dalam mengajarkan membaca permulaan yang lebih tepat dan efektif. Metode B3 dapat dijadikan strategi pembelajaran oleh guru dalam pengenalaan huruf dasar yaitu huruf vokal dan konsonan. Dapat membantu aspek perkembangan anak.

\section{Indikator Keberhasilan Pembelajaran Membaca Permulaan Pada Anak Usia 5-6 Tahun Dengan Menggunakan Metode B3 (Bernyanyi, Bercerita \& Bermain)}


Indikator keberhasilan pembelajaran membaca permulaan pada anak usia 5-6 tahun dengan menggunakan metode B3 (Bernyanyi, Bercerita \& Bermain). Pembelajaran membaca permulaan dengan menggunakan metode B3 (Bernyanyi, Bercerita \& Bermain) sangat efektif diaplikasikan untuk siswa kelompok B1. Indikator penilaian siswa disesuaikan dengan standar tingkat pencapaian pengembangan yang ada didalam Permendikbud No. 137. Sehingga penilaian disesuaikan dengan usia anak.

Media dan alat peraga membantu para guru dalam menyajikan pembelajaran yang menyenangkan. Anak-anak tidak mudah jenuh, fokus dan lebih kondusif dalam belajar. sesuai dengan teori Thomson bahwa pembelajaran harus dikemas dengan menarik, asyik, dan menyenangkan. Pembelajaran membaca permulaan dilakukan dengan permainan-permainan yang menarik sehingga anak merasa senang, dan tanpa disadari anak lebih cepat mengingat huruf yang sedang dipelajari.

Metode yang dipilih untuk program pembelajaran membaca permulaan sangat mudah digunakan para guru. Metode bernyanyi, bercerita dan bermain merupakan metode yang selalu ada dan selalu digunakan disetiap lembaga paud manapun. Dengan adanya metode B3 para guru dapat menggunakannya dimanapun dan kapanpun, karena dari 3 metode tersebut tidak membutuhkan waktu yang sangat lama dan dapat digunakan 1 hari kegiatan langsung. Kelebihan dari metode B3 ini adalah guru cepat menguasai metode, dapat digunakan dimanapun dan kapanpun. Sedangkan kekurangan metode B3 ini adalah guru perlu menyiapkan media pembelajaran yang banyak sehingga memerlukan waktu yang lumayan cukup lama dan biaya untuk pembuatan media yang lumayan cukup tinggi.

\section{Kesimpulan}

Berdasarkan hasil dari pembahasan dan analisis data yang telah dilakukan mengenai pengembangan metode b3 (bernyanyi, bercerita \& bermain) dalam meningkatkan kemampuan membaca permulaan pada anak usia 5-6 tahun di TKQ Xdapat disimpulkan sebagai berikut:

1. Program Pembelajaran Membaca Permulaan Di Taman Kanak-Kanak Qur'an Az-Zahra Membaca permulaan untuk anak usia 5-6 tahun merupakan program pembelajaran di TKQ Xyang ada pada program misi sekolah point ke empat. Program membaca di Taman Kanak-Kanak Qur'an Az-Zahra merupakan suatu proses pengenalan huruf dasar berupa huruf vokal, suku kata, kata hingga kalimat. Tujuan pembelajaran membaca permulaan di Taman Kanak-Kanak Qur'an Az-Zahra yaitu memenuhi kebutuhan masyarakat sekitar dalam mempersiapkan putera-puterinya untuk memasuki jenjang sekolah dasar.

2. Proses Pembelajaran Membaca Permulaan Menggunakan Metode B3 (Bernyanyi, Bercerita \& Bermain)

Proses pembelajaran membaca permulaan dengan menggunakan metode B3 (Bernyanyi, Bercerita \& Bermain) diberikan secara bertahap, mulai dari tahap 1 pengenalan huruf vokal, tahap 2 pengenalan suku kata ba,bi,bu,be,bo, tahap 3 pengenalan suku kata ca,ci,cu,ce,co dan tahap 4 pengenalan gabungan suku kata.

Adapun hasil dari proses pembelajaran membaca menggunakan metode B3 yaitu, proses membaca menngunakan metode bernyanyi memperoleh skor presentase 64,25\%, sedangkan proses membaca menggunakan metode bercerita memperoleh skor presentase $56,68 \%$ dan proses membaca menggunakan metode bermain memperoleh skor presentase $77,65 \%$.

3. Peran Alat Peraga Dan Media Dalam Pembelajaran Membaca Permulaan

Peran alat peraga dan media pembelajaran membaca permulaan dengan menggunakan metode B3 (Bernyanyi, Bercerita \& Bermain) memiliki peran penting sebagai sarana pendukung proses pembelajaran membaca permulaan. Dengan adanya alat dan media pembelajaran membantu guru dalam menyajikan pembelajaran yang efektif dan menciptakan suasana kelas yang hangat dan menyenangkan. Membatu guru mengenalkan huruf kepada siswa dengan cara yang tepat, asyik dan menyenangkan sehingga anak tidak menjadikan suatu beban dalam belajar. Melalui media dan alat pembelajaran membaca permulaan siswa sangat terlihat senang dan antusiasme yang 
tinggi.

4. Peran Guru Dalam Proses Pembelajaran Membaca Permulaan Dengan Menggunakan Metode B3 (Bernyanyi, Bercerita \& Bermain)

Peran guru dalam proses pembelajaran membaca permulaan dengan menggunakan metode B3 yaitu mempersiapkan media dan alat pembelajaran yang akan digunakan, menggunakan metode secara bertahap dan berkesinambungan, memanfaatkan media pembelajaran untuk menciptakan suasana kelas yang hangat, aktif dan menyenangkan bagi anak.

5. Indikator Keberhasilan Pembelajaran Membaca Permulaan Pada Anak Usia 5-6 Tahun Dengan Menggunakan Metode B3 (Bernyanyi, Bercerita \& Bermain)

Indikator keberhasilan pembelajaran membaca permulaan dengan menggunakan metode B3 yaitu program dibuat disesuaikan dengan materi paud, dan disesuaikan dengan kemampuan siswa yang ada di standar tingkat pencapaian perkembangan anak usia dini. metode yang dipilih mudah digunakan oleh siapa saja baik orang tua murid atau guru paud. Metode B3 (Bernyanyi, Bercerita \& Bermain) dapat digunakan kapanpun dan dimanapun.

\section{Daftar Pustaka}

[1] Aaker, A. David. 2002. Ekuitas Merek (Edisi Indonesia). Jakarta: Mitra Utama.

[2] Arikunto. 2010. Prosedur Penelitian: Suatu Pendekatan Praktek. Jakarta: Rineka Cipta

[3] Arikunto, Suharsimi. 2006. Prosedur Penelitian: Suatu Pendekatan Praktik (edisi revisi vi). Jakarta: PT Asdi Mahasatya

[4] Aulina, C N. 2012. Pengaruh Permainan Kosakata Terhadap Kemampuan Membaca Permulaan Anak Usia 5-6 Tahun. PEDAGODIA: Jurnal Pendidikan

[5] Beaty, Janice J. 3013. Observasi Perkembangan Anak Usia Dini. Jakarta: Kencana Prenadamedia Group

[6] Hamzah, Amir. 2019. Metode Penelitian \& Pengembangan ( $R \& D)$. Malang: CV. Literasi Nusantara Abadi

[7] Inten, D N. dkk. (2016). Literasi Dini Melalui Teknik Bernyanyi. Jurnal AL-MURABBI: Jurnal Studi Kependidikan dan Keislaman

[8] Isnaningsih, Anti. 2016. Pengaruh Metode Pembelajaran Bahasa Melalui Bernyanyi Dan Bercerita Terhadap Penugasan Kosa Kata Bahasa Indonesia Anak TK ABA Seropandlingo Bantul Yogyakarta. Yogyakarta: Universitas Negri Yogyakarta

[9] Madyawati, Lilis. 2016. Strategi Pengembangan Bahasa Pada Anak. Jakarta: Prenadamedia Group

[10] Masnipal. 2018. Menjadi Guru Paud Profesional. Bandung: PT. Remaja Rosdakarya

[11] Masnipal, Arif Hakim. 2018. "Perbedaan Pendapat Pembelajaran Prabaca, Pratulis dan Prahitung Bagi Anak Usia Dini”, https://doi.org/10.29313/ga.v2i1.3855 diakses pada 1 Juni 2018

[12] Hamzah, Amir. 2019. Metode Penelitian \& Pengembangan (Research \& Development). Malang: Literasi Nusantara

[13] Paramita, Vidya Dwina. 2020. Montessori: Keajaiban Membaca Tanpa Mengeja. Yogyakarta: PT. Bentang Pustaka

[14] Permatasari A N, dkk. 2017. Literasi Dini Dengan Teknik Bercerita.

[15] Pujiastuti, Anita. 2010. Peningkatan Minat Membaca Anak Usia Dini Melalui Kegiatan Cerita Bergambar Pada Kelompok B di TK Dharma Putra. Surakarta: FKIP-UMS

[16] Rohman, Syaifur. 2017. Membangun Budaya Membaca Pada Anak Melalui Program Gerakan Literasi Sekolah. TERAMPIL: Jurnal Pendidikan dan Pembelajaran Dsar 4

[17] Risaldy, Sabil. 2014. Bermain, Bercerita dan Bernyanyi Bagi Anak Usia Dini. Jakarta: PT. Luxima Metro Media

[18] Setiantono, Try. 2012. Pengaruh Metode Bercerita Bagi Anak Usia Dini Di PAUD Smart 
Pengembangan Metode B3 (Bernyanyi, Bercerita, \& Bermain) dalam Meningkatkan Kemampuan ... | 45

Little Cilame IndahBandung. Jurnal: Empowerment (Jurnal ilmiah program studi pendidikan luar sekolah) 